\title{
Peran Budaya Perusahaan Terhadap Usaha Penciptaan Kinerja Karyawan
}

\author{
Zhiella Sabrina Darwis ${ }^{1}$, dan Syafiq Basri Assegaff ${ }^{2}$ \\ ${ }^{1,2}$ Institut Komunikasi dan Bisnis LSPR, Jakarta, Indonesia
}

\begin{abstract}
ABSTRAK
Penelitian ini bertujuan untuk mengetahui peran budaya organisasi dalam meningkatkan kinerja karyawan pada PT Telekomunikasi Indonesia, Tbk khususnya karyawan senior pada subdit Human Capital Strategic Management. PT Telekomunikasi Indonesia, Tbk menciptakan satu tim yang bernama Culture Agent untuk mengkomunikasikan perubahan budaya yang terjadi pada PT Telekomunikasi Indonesia, Tbk. Dalam hasil penelitian dapat disimpulkan bahwa perubahan budaya organisasi dapat meningkatkan kinerja karyawan dalam menyelesaikan tugas yang diberikan. Dan juga dapat menghilangkan sikap senioritas yang ada pada PT Telekomunikasi Indonesia, Tbk.
\end{abstract}

Kata kunci: budaya, organisasi, agen, kinerja, karyawan

\section{The Role of Corporate Culture on Employee Performance Creation Efforts}

\begin{abstract}
This study aims to determine the role of organizational culture in improving employee performance at PT Telekomunikasi Indonesia, Tbk, especially senior employees at the Human Capital Strategic Management division. PT Telekomunikasi Indonesia, Tbk create a team named Culture Agent to communicate about the transformation of the culture in company. In the results of the study it can be concluded that changes in organizational culture can improve employee performance in completing the given task. And also can eliminate the seniority attitude that exists in PT Telekomunikasi Indonesia, Tbk.
\end{abstract}

Keywords: culture, organization, agency, performance, employees

\section{PENDAHULUAN}

Sehubungan dengan perubahan zaman yang semakin maju didukung juga dengan perkembangan teknologi dan hampir merubah semua sistem berubah menjadi digital (Ciputra \& Prasetya, 2020). Dengan adanya perubahan ini tentu akan mendorong masyarakat untuk mengubah masyarakat untuk mengubah gaya hidup, begitu juga dengan gaya kerja yang mengikuti perkembangan zaman. Banyak perusahaan yang melakukan transformasi budaya secara besar-besaran menjadi lebih digital (Pratiwi \& Mahdiah, 2020). Fenomena ini pun terjadi di Indonesia, salah satu perusahaan besar yang melakukan perubahan pada budaya 
perusahaannya adalah PT Telekomunikasi Indonesia, Tbk atau yang biasa di sebut Telkom. Telkom adalah salah satu perusahaan penyedia layanan komunikasi dan jaringan terbesar di Indonesia, Telkom juga merupakan salah satu perusahaan milik negara. Telkom merupakan perusahaan BUMN pertama yang melakukan perubahan terhadap budaya organisasi.

Dalam penelitian ini teori yang utama yang digunakan adalah teori komunikasi menurut Muhammad (2009) yang menggambarkan digambarkan sebagai proses untuk mencipatakan dan terjadinya tukar pesan dalam satu jaringan hubungan yang saling bergantung satu sama lain untuk mengatasi suatu keadaan yang selalu berubah - ubah. Max Weber mengatakan bahwa organisasi sebagai sesuatu yang hierarki dan diatur oleh aturan. Weber juga mendefinisikan sebuah organisasi sebagai sebuah system kegiatan interpersonal yang memiliki maksud tertentu yang dirancang untuk menyelaraskan tugas-tugas individu. Menurut Weber antara organisasi dan kelompok memiliki perbedaan yang terletak pada adanya birokrasi. Organisasi memiliki sistem yang dapat mengatur dirinya sendiri yaitu birokrasi, sedangkan kelompok biasanya yang bukan organisasi tidak memiliki sistem birokrasi (Morissan, 2009).

Malina (2012) menjabarkan bahwa teori Human Capital menganggap bahwa profil bisnis berkembang dan berkelanjutan ketika perusahaan mampu menghasilkan barang dan jasa sesuai dengan kebutuhan pelanggan dengan baik daripada yang ditawarkan pesaingnya, dapat diartikan perusahaan tersebut memiliki keunggulan kompetitif. Keunggulan yang berlangsung lama dan berlanjut selalu berorientasi pada dinamika kebutuhan pelanggan. Pengembangan Human Capital ini antara lain dapat dilakukan melalui beberapa cara, yaitu internalisasi Corporate Culture, memastikan pelaksanaan Good Corporate Governance, mengembangkan SDM professional sebagai human capital yang produkti dan prudent, menciptakan pemimpin atau leader sebagai role model \& people manager, dan yang terakhir menegakkan dan meningkatkan kepatuhan hukum.

Culture Agent adalah suatu organisasi yang diciptakan oleh Telkom yang bertugas untuk mensosialisasikan dan mendorong karyawan untuk melakukan perubahan budaya organisasi. Culture agent mampu memahami program culture dan memahami perlunya melakukan shifting budaya untuk mendukungnya Visi dan Misi perusahaan, mendapatkan informasi baru tentang perkembangan bisnis dan apa yang menjadi kaitannya dengan budaya perusahaan, dan juga diharapkan Culture Agent mampu memberikan sharing experience antar Culture Agent yang berkaitan dengan implementasi aktivasi budaya.

Budaya organisasi merupakan bagian penting dalam memahami masyarakat dalam waktu yang panjang (Rivai, 2003). Sedangkan Soetopo (2010) mengatakan bahwa budaya organisasi ialah kerangka kognitif, yang meliputi sikap, nilai, norma perilaku, dan ekspektasi yang dimiliki oleh masing-masing anggota organisasi. Budaya organisasi akan tercermin pada karyawannya, bagaimana cara menjalankan tugas dan dalam mengelola sumber daya yang diperlukan untuk mencapai tujuan. Budaya juga mempengaruhi jalannya masing-masing individu dalam mengambil keputusan dan bertindak sebagai tanggapan terhadap peluang.

Kinerja atau prestasi adalah suatu pencapaian atau hasil kerja secara kualitas dan kuantitas yang 
oleh seseorang karyawan dalam menyelesaikan tugasnya atau tanggung jawabnya yang telah diberikan kepadanya (Mangkunegara, 2009). Sedangkan menurut Sandy (2015) menjabarkan bahwa kinerja adalah prestasi yang dicapai pegawai dalam menjalankan tugas yang diberikan kepadanya.

\section{METODE PENELITIAN}

Metode yang digunakan adalah metode kualitatif, peneliti melakukan wawancara dan observasi. Menurut Creswell (2003) penelitian kualitatif adalah pendekatan untuk membangun pernyataan pengetahuan berdasarkan perspektif - konstruktif (makna - makna yang bersumber dari pengalaman individu, nilai - nilai social dan sejarah, dengan tujuan untuk membangun teori atau pola pengetahuan tertentu), atau berdasarkan perspektif partisipatori (misalnya orientasi terhadap politik, isu, kolaborasi, atau perubahan), atau keduanya.

Menurut Moleong (2010) kriteria keabsahan data ada empat macam, yaitu: kepercayaan, keteralihan, ketergantungan, dan kepastian. Pada penelitian ini peneliti menggunakan teknik triangulasi untuk memeriksa keabsahan data yang sudah didapat oleh peneliti. Triangulasi didefinisikan sebagai kombinasi beberapa metode yang dipakai untuk mengkaji fenomena yang saling terkait dari sudut pandang dan perspektif yang berbeda. Triangulasi dibagi menjadi 4, yaitu: (1) triangulasi metode, (2) triangulasi antar-peneliti (jika dalam kelompok), (3) triangulasi sumber data, dan (4) triangulasi teori.

\section{HASIL DAN PEMBAHASAN}

Dalam membahas hasil penelitian ini, peneliti merujuk pada kinerja karyawan yang meningkat setelah Telkom melakukan transformasi budaya pada organisasi. Keberhasilan ini dapat diukur oleh indikator kinerja, menurut Moeheriono (2012) mengatakan bahwa indikator kinerja dapat dikatakan sebagai nilai atau karakteristik tertentu yang dapat mengukur outcome atau hasil suatu kegiatan. Telkom memiliki beberapa tolak ukur untuk mengukur sejauh mana keberhasilan mereka dalam meningkatkan kinerja karyawannya melalui budaya organisasi, diantaranya adalah KPI dan Matrix. Yang akan dilakukan penghitungan di setiap tahunnya. Dari hasil analisis yang sudah dilakukan Peneliti dapat disimpulkan bahwa perubahan budaya organisasi yang ada pada PT Telekomunikasi Indonesia, Tbk sudah memberikan dampak positif terhadap kinerja karyawan (Dhara et al., 2020).

\section{SIMPULAN}

Adapun simpulan dari hasil penelitian ini sebagai berikut perubahan budaya organisasi yang terjadi pada PT Telekomunikasi Indonesia, Tbk dianggap berhasil meningkatkan kinerja karyawan khususnya pada subdit HCSM. Kendala yang sering terjadi dilapangan adalah informasi yang tidak tersampaikan dengan sempurna, hal ini meyebabkan banyaknya karyawan yang tidak mengetahui info-info terbaru. Upaya yang dilakukan oleh Team Culture Agent dengan melalui berbagai macam cara, seperti calendar of event dan kegiatan-kegiatan lainnya. 
Karena dengan melalui suatu kegiatan event yang ada dianggap lebih mudah untuk memberikan masukan-masukan terhadap karyawan senior. Sejak PT Telekomunikasi Indonesia, Tbk melakukan budaya organisasi menjadi yang lebih modern dan digital, hal ini memaksa karyawan yang baby boomers untuk merubah pola berpikirnya menjadi lebih modern sehingga senioritas di lapangan lama lama hilang.

\section{DAFTAR PUSTAKA}

Ciputra, W., \& Prasetya, W. (2020). Analisis Pengaruh E-Service Quality, Perceived Value Terhadap Customer Satisfaction, Trust, dan Customer Behavioral Intention. COMMENTATE: Journal of Communication Management, 1(2), 109-128.

Creswell, J. W. (2003). Research Design Qualitative, Quantitative and Mixed Methods Approaches Second Edition. New Delhi: Sage Publications.

Dhara, K., Hutomo, K., Brigitta, L., \& Arzella, N. (2020). Penggunaan Instagram Sebagai Media Kampanye Politik pada Pemilihan Kepala Daerah DKI Jakarta 2017. COMMENTATE: Journal of Communication Management, 1(2), 193-207.

Mangkunegara, Achmad Prabu (2009). Manajemen Sumber Daya Manusia. Bandung: PT Remaja Rosdakarya.

Moeheriono. (2012). Pengukuran Kinerja Berbasis Kompetensi. Jakarta: Raja Grafindo Persada.

Moleong, Lexy J. (2004). Metodologi Penelitian Kualitatif. Bandung: PT. Remaja Rosdakarya.

Moleong, Lexy J. (2010), Metodologi penelitian kualitatif. Bandung: PT. Remaja Rosdakarya.

Morissan. (2009). Teori Komunikasi Organisasi. Bogor: Ghalia Indonesia.

Pratiwi, A. M., \& Mahdiah, M. (2020). Special Event Sebagai Sarana Meningkatkan Citra Panasonic Beauty. COMMENTATE: Journal of Communication Management, 1(1), $57-71$.

Rivai, Veitzal. (2003). Manajemen Sumber Daya Manusia untuk Perusahaan : Dari Teori ke Praktik. Jakarta: PT.Rajagrafindo Persada.

Ruslan, Rosady. (2008). Manajemen Public Relations \& Media Komunikasi. Jakarta: PT Rajagrafindo Persada.

Soetopo, Hendyat. (2010). Perilaku Organisasi Teori. Bandung: PT Remaja Rosdakarya.

Sugiyono. (2013). Metodelogi Penelitian Kuantitatif, Kualitatif Dan R\&D. Bandung: Alfabeta. 